\title{
The assessment of seafarers' knowledge, attitudes and practices related to STI/HIV/AIDS in northern Morocco
}

\author{
Salwa Laraqui ${ }^{1,2}$, Omar Laraqui ${ }^{3}$, Nadia Manar ${ }^{1,2}$, Tarik Ghailan², \\ Mohamed Belabsir ${ }^{2}$, Frederic Deschamps ${ }^{3}$, Chakib H. Laraqui ${ }^{1,2}$
}

\author{
${ }^{1}$ Ecole Supérieure D'ingénierie De La Santé, Casablanca, Morocco \\ ${ }^{2}$ Association Marocaine De Recherche En Santé Au Travail, 39, Bd Lalla Yacout, Casablanca, Morocco \\ ${ }^{3}$ Institut Universitaire De Médecine Et Santé Au Travail, Reims, France
}

\begin{abstract}
Background: The purpose of this study was to assess the knowledge, attitudes and practices of seafarers in relation to sexually transmitted infections (STI) and human immunodeficiency virus (HIV)/acquired immune deficiency syndrome (AIDS).

Materials and methods: This transversal, descriptive and behavioural study was conducted in 2014 on a representative sample of 1447 seafarers.

Results: The rate of participation was 95\%. The mean age was $36.1 \pm 8.2$ years. Knowledge about transmission and prevention mode was satisfactory on HIV/AIDS; however, some misconceptions still persist. The level of stigmatisation and discrimination towards people living with the virus was considered high. The prevalence of sexual high-risk behaviour was significant: $32 \%$ had at least two sexual partners and $26.3 \%$ have had sex with sex workers, $60 \%$ of them were not protected; $42.8 \%$ have never used the condom and only $15.1 \%$ used it systematically. The sailors who had sexual intercourse under the influence of alcohol or drugs are less protected. As too HIV testing, only $10.2 \%$ did it.

Conclusions: This study showed a gap in knowledge about transmission and prevention of HIV infection/AIDS and sexual risk behaviour. Increasing awareness and information among seafarers is of prime importance.
\end{abstract}

(Int Marit Health 2017; 68, 1: 26-30)

Key words: attitudes, knowledge, practices, seafarers, STI/HIV/AIDS

\section{INTRODUCTION}

Although at the international level, the number of new human immunodeficiency virus (HIV) infections is continuously decreasing, in North Africa HIV infection incidence increased by $7 \%$ between 2005 and 2013 [1] and in Morocco $50 \%$ of the cases were noted between 2009 and 2014 [2]. However, the prevalence in our country remains low and relatively stable within the general population (around $0.14 \%$ ). Nevertheless, it is higher in risk groups such as sex professionals $(2 \%)$, homosexual men (4.5\%), injectable drugs users (14\%) and the migrants (4.5\%) [2].
Because of their geographical mobility, long periods of sexual abstinence with their own wife and frequent relations with sex workers, seafarers are especially vulnerable to sexually transmitted infections (STI)/acquired immune deficiency syndrome (AIDS) [3]. Although no studies were dedicated to knowledge, attitudes and practices related to STI/HIV/AIDS among fishermen, they still have abnormally high rates of HIV in comparison with their communities of origin [4]. This study will definitely help in the fight against HIV/AIDS by giving the necessary information to the people involved in ensuring efficient education and awareness campaigns and social marketing actions promoting the use of the condoms.

Prof. Chakib H. Laraqui, 39 Boulevard LallaYacount, Casablanca, Morocco, tel/fax: 002125224455 84, e-mail: chlaraqui51@gmail.com 


\section{MATERIALS AND METHODS SUBJECTS}

This epidemiological, observational and cross sectional study was conducted in three ports of the northern Morocco in 2014. It was concerned a representative sample of 1447 traditional male sailors older than 18 years with length of employment above one year.

\section{METHODS}

The survey support is an individual and anonymous questionnaire, inspired by documents that UNAIDS has provided about behavioural surveillance. It contains four articles reporting about socio-demographic and professional data, risk behaviours, knowledge of STI/AIDS, attitudes and beliefs towards STI/AIDS and also an invitation to an anonymous screening.

Prior to implementation of this survey, we have contacted the officers of fishermen's association to explain the goal behind the study and obtain the assistance of their occupational physicians. Interviews took place in the occupational health units of the port, in all confidentiality informing all the participants about the interest of our study. They lasted between 15 to $20 \mathrm{~min}$ for each individual. The questions were verbally formulated, in a simple and accessible terms for all. Four investigating doctors collected the data as part of their diploma capstone in occupational medicine.

The statistic study is based on the analysis of variance and on the Student test to compare the averages. In terms of qualitative variables, it was based on the $\chi^{2}$ test with or without Yates correction for a certain degree of freedom. The chosen significance level corresponded to a value of $p$ of 0.05 . The software used is the Epi info version $6.04 \mathrm{dfr}$.

\section{RESULTS \\ SOCIO-DEMOGRAPHIC AND PROFESSIONAL CHARACTERISTICS OF THE POPULATION}

One thousand three hundred and seventy-six sailors filled up the questionnaire, equal to a total number of global participation of 95 . The average age was $36.1 \pm 8.2$ years of age with extremes of 18 and 69 years. The sailors aged 40 and less represented $59.9 \%$ and the married ones $60.8 \%$ (Table 1).

\section{KNOWLEDGE EVALUATION ON THE STI/HIV/AIDS}

Ways of transmission. All sailors heard about HIV. The modes of transmission mentioned were unprotected sexual intercourses (98\%), blood stained objects usage (91\%), maternal foetal transmission (78.3\%) and breastfeeding (54.2\%). For the incorrect modes of transmission, $81.1 \%$ believed that STI could be contracted by getting exposed to cold, $42.2 \%$ by sharing a meal with an HIV-positive person, $41.2 \%$ in a public bath and $53.9 \%$ by mosquito bites (Table 2 ).
Table 1. Socio-demographic and socio-professional characteristics $(n=1376)$

\begin{tabular}{|c|c|}
\hline Characteristics & $\mathbf{N}(\%)$ \\
\hline \multicolumn{2}{|l|}{ Age } \\
\hline $18-30$ & $449(32.6 \%)$ \\
\hline $30-40$ & $376(27.3 \%)$ \\
\hline $40-50$ & $271(19.6 \%)$ \\
\hline $50-60$ & $245(17.8 \%)$ \\
\hline$\geq 60$ & $35(2.5 \%)$ \\
\hline \multicolumn{2}{|l|}{ Marital status } \\
\hline Married and living with wife & $798(58 \%)$ \\
\hline Married and having another sexual partner & $39(2.8 \%)$ \\
\hline Not married living with a sexual partner & $140(10.1 \%)$ \\
\hline Not married and not living with a sexual partner & $392(28.5 \%)$ \\
\hline No answer & $7(0.5 \%)$ \\
\hline \multicolumn{2}{|l|}{ Habitation } \\
\hline Alone & $127(9.2 \%)$ \\
\hline With the family & $1094(79.5 \%)$ \\
\hline Colleagues & $140(10.2 \%)$ \\
\hline Other & $12(0.9 \%)$ \\
\hline No answer & $3(0.2 \%)$ \\
\hline \multicolumn{2}{|l|}{ Level of education } \\
\hline Illiterate & $217(15.7 \%)$ \\
\hline Primary & $758(55.1 \%)$ \\
\hline Secondary & $372(27 \%)$ \\
\hline College & $29(2.1 \%)$ \\
\hline \multicolumn{2}{|l|}{ Toxic habits } \\
\hline Tobacco & $607(44.1 \%)$ \\
\hline Alcohol & $802(58.3 \%)$ \\
\hline Cannabis & $520(37.8 \%)$ \\
\hline Hashish & $593(43.1 \%)$ \\
\hline Psychotropic substances & $54(3.9 \%)$ \\
\hline \multicolumn{2}{|l|}{ Socio-professional categories } \\
\hline Pilot & $141(10.2 \%)$ \\
\hline Co-pilot & $70(5.1 \%)$ \\
\hline Mechanic on board & $88(6.4 \%)$ \\
\hline Fisherman & $1054(76.6 \%)$ \\
\hline Other & $23(1.7 \%)$ \\
\hline Social security & $659(76.7 \%)$ \\
\hline
\end{tabular}

Ways of prevention. Eighty per cent mentioned the use of condoms and the fidelity of the couple (Table 2) and $47.3 \%$ thought STI could be prevented by urinating post an unprotected sexual intercourse. For the principal places for obtaining the condoms, $98.3 \%$ of sailors mentioned pharmacies, $13.1 \%$ health centres and 3.9\% non-governmental organisations.

STI symptoms. The most frequently cited STI symptoms both by men and women, with respective rates of $50.1 \%$ and $57.3 \%$, was abnormal genital leakage (Table 3). Sixteen point nine per cent of men and $42.6 \%$ of women did not know any symptom. 
Table 2. Prevalence of the knowledge on the modes of transmission and prevention of the HIV/AIDS $(n=1376)$

$\begin{array}{ll}\text { Modes of transmission } & 1348(98 \%) \\ \text { Sexual intercourse } & 742(53.9 \%) \\ \text { Mosquito bites } & 1255(91.2 \%) \\ \begin{array}{l}\text { Injection with a needle already used } \\ \text { by another person }\end{array} & 1251(90.9 \%) \\ \begin{array}{l}\text { Shaving with a blade already used } \\ \text { by another person }\end{array} & 1077(78.3 \%) \\ \begin{array}{l}\text { Maternal foetal transmission } \\ \text { Breastfeeding }\end{array} & 746(54.2 \%) \\ \begin{array}{l}\text { Modes of prevention } \\ \text { Systematic use of a condom }\end{array} & 1110(80.7 \%) \\ \begin{array}{l}\text { Sexual intercourse with one faithful } \\ \text { and uninfected partner }\end{array} & 1098(79.8 \%)\end{array}$

Table 3. Knowledge of the symptoms of the STI by the seafarers

\begin{tabular}{lll}
\hline STI symptoms & $\begin{array}{l}\text { In women } \\
\text { (n = 1319) }\end{array}$ & $\begin{array}{l}\text { In men } \\
\text { (n = 1319) }\end{array}$ \\
\hline Abdominal pain & $115(8.7 \%)$ & - \\
Fetid vaginal discharge & $661(50.1 \%)$ & - \\
Urethral discharge & - & $756(57.3 \%)$ \\
Micturition burns & $82(6.2 \%)$ & $397(30.1 \%)$ \\
Genital ulcerations & $117(8.9 \%)$ & $265(20.1 \%)$ \\
Tumefaction of the groin & $16(1.2 \%)$ & $462(35 \%)$ \\
Genital itching & $110(8.3 \%)$ & -
\end{tabular}

Table 4. Sources of raising awareness on the HIV/AIDS during the past year $(n=1007)$

$\begin{array}{ll}\text { Education session on AIDS } & 80(8 \%) \\ \text { Film about HIV/AIDS } & 43(4.2 \%) \\ \text { Radio programme on AIDS } & 459(45.6 \%) \\ \text { Poster on HIV/AIDS } & 132(13.1 \%) \\ \text { TV programme on HIV/AIDS } & 735(73 \%) \\ \text { Advice from a health worker } & 40(4 \%) \\ \text { Advice from an association agent } & 75(7.4 \%)\end{array}$

Table 5. Reasons for no-use of condoms during the last sexual intercourse $(n=959)$

$\begin{array}{ll}\text { Condom was not available } & 90(9.4 \%) \\ \text { Condom was too expansive } & 11(1.1 \%) \\ \text { Condom was refused by the partner } & 9(0.9 \%) \\ \text { I don't like condom } & 365(38 \%) \\ \text { Condom was not necessary } & 312(32.5 \%) \\ \text { I didn't think about it } & 172(17.9 \%)\end{array}$

Sources of information. During the year prior to the study, $73.2 \%$ of seafarers were informed about the prevention of STI/HIV/AIDS through different ways, mainly the media (73\% via TV and $45.6 \%$ via radio) (Table 4 ).

\section{EVALUATION OF ATTITUDES AND SEXUAL PRACTICES}

The average age of the first sexual intercourse was of $16.5 \pm 1.6$ years of age. Among the 1334 respondents who had sex intercourses during the last month, the average number of sexual partners was 1.4. Thirty two per cent had at least two sexual partners and $26.3 \%$ had sexual intercourse with sex professionals, of which $60 \%$ were not protected.

Condom use at the last sexual intercourse was reported only by $28 \%$ of respondents; in $71.9 \%$ of the cases condom use was proposed by the sailors, in $12 \%$ by the sexual partner and in $16.1 \%$ was decided by mutual agreement. Forty-two point eight per cent of the seafarers have never used a condom, $29.8 \%$ used the condoms rarely and only $15.1 \%$ systematically. Of these, $39 \%$ had a secondary level education.

Concerning the main reasons for not using the condom, $38 \%$ of the sailors said they did not like it, $17.9 \%$ had not thought of it and $32.5 \%$ claimed that the use of condom was not necessary because they were married (Table 5).

Thirty point three per cent had often had sexual intercourse while under the influence of alcohol or drugs, of which $44 \%$ did not use any protection.

Twenty point three per cent reported having a history of genital discharge in the past 12 months and $7.1 \%$ genital ulcerations.

During the last episode of sexually transmitted infection, $37.8 \%$ had consulted a private doctor, $28.2 \%$ a public health centre, $27 \%$ a pharmacist, $3.2 \%$ a traditional therapist and $3.8 \%$ opted for self-medication.

Fifty-eight point one per cent avoided sexual intercourse during the infection period and only $4.3 \%$ used condoms. Only $15.3 \%$ informed their partners.

Forty-five point two per cent refused to share a meal with an HIV-positive person and $53.1 \%$ believed that a sailor who's not sick but has HIV should not be allowed to work.

Only $19 \%$ have a positive perception of screening for HIV infection and $10.2 \%$ had done the test.

\section{DISCUSSION \\ KNOWLEDGE ABOUT STI/AIDS}

Knowing about HIV transmission and preventions is fundamental in decreasing the rate of HIV infections. Misconceptions about this infection vary and may lead to misinterpretations/confusion, countering prevention efforts and maintaining the spread of the disease. Our study showed that seafarers had some satisfactory knowledge of the 
modes of transmission: $98 \%$ knew that this infection can be acquired through unprotected sexual intercourse and 91\% that through blood. These results were comparable to those found in seafarers in the Indian Ocean countries (97\% and $72 \%$ ) [5] and the Nigerian seafarers of which $90 \%$ were aware of the principal modes of transmission [6]. They were better than seafarers in Senegal (96.5\% and 63.5) [7, 8], in Kiribati (72.5\%) [9] and in the Philippines (7\%) [10].

However, among our sailors misconceptions persisted, especially concerning the possibility of contamination through mosquito bites (53.9\%) and sharing a meal with an HIV positive person (45.2\%). Those rates are similar to those found among Filipino seafarers (52.1\% and 37.7\%) [10] and Indian ones (54\% and 38\%) [5], while the Senegalese seafarers were better informed since $41.3 \%$ of them negated mosquito bites as a mode of transmission and $86.2 \%$ rejected transmission by sharing a meal with a seropositive person $[7,8]$. The frequency of those misconceptions explains partly the high level of stigmatisation, since $53.1 \%$ of our fishermen thought that an HIV positive person should not be allowed to work. This attitude was reported in similar surveys in countries of the Indian Ocean, in Nigeria and in Senegal [5-7]. In the Philippines, only $4 \%$ of seafarers had a positive attitude towards HIV positive people. Concerning the prevention ways, $80 \%$ of our sailors had mentioned the use of condoms and marital fidelity. This prevalence was similar to that found in Kiribati [9] and higher than in the Philippines (72.7\%) [10] and Senegal (61.6\%) [8]. This level of knowledge about the transmission and prevention demonstrates the importance of the information and awareness-raising role of mass media, which are the main sources cited by sailors [7-11]. The role of non-governmental organisations and health structures remain very limited.

\section{SEXUAL ATTITUDES AND BEHAVIOURS}

A gap has been noted in the knowledge how to prevent the HIV infection and about the risky sexual behaviour. In fact, 32\% of our surveyed subjects who had sexual intercourses during the last month had at least two sexual partners and $26.3 \%$ had sexual intercourses with sex professionals of which $60 \%$ were unprotected. This prevalence was higher than in the Senegal sailors [8], those of the Indian Ocean countries [5] and the Philippines [10]. The presence of sex professionals near ports, the sailors' mobile lives and the fact they are constantly far away from home, all helped encouraging extra marital relationships [8]. Forty-two point eight per cent of our sailors have never used a condom, $29.8 \%$ used condoms rarely, and only $15.1 \%$ systematically against 56.3\% in Italy [11], 42.3\% in Kiribati [9] and 35\% in Nigeria [6].

The level of education has proven to be a favourable factor in the use of condoms. In fact, 39\% of our subjects using it systematically had a high school degree. The same results were reported within mobile populations of India [12].

As for not using a condom, $38 \%$ of our sample declared dislike of using one. Thirty-three point eight per cent of sailors from Senegal and all the ones from the Philippines had reported that the use of condoms reduces sexual pleasure $[8,13]$. Paradoxically, married sailors were those who used condoms the least with sex professionals [5]. In fact, thirty-two point five per cent of our population were married and felt that the use of condom was not necessary. Comparable results were reported in other studies [5-8]. The less frequent use of condom for married men could be explained by a lack of habit. Awareness rising among married men can contribute to the reduction of HIV prevalence among spouses.

The average number of sexual partners in our sailors was 1.4. Thirty two per cent had had at least two sexual partners. These data were higher than those reported in the general Moroccan population [2]. The multi-partnership and the irregular usage of condom were the subject of many studies $[5,9]$.

Unprotected sexual intercourse was favoured by the consumption of alcohol, which decreases the inhibition level [8]. In our query, $30.3 \%$ had often had sex while under the influence of alcohol or drugs, $44 \%$ of them never used condoms. A comparable prevalence (29.8\%) was noticed among sailors in the countries of the Indian Ocean [5]. The high frequency of alcohol consumption by the fishermen can be explained by the stress and risky work conditions. Awareness campaigns against toxic habits are necessary.

The high prevalence of STI among our seafarers requires information actions, education and communication about the prevention. Twenty-four point seven per cent of our sample had reported having an antecedent of STI in the last 12 months. A lower prevalence of $10 \%$ was noted in the member countries of the Indian Ocean Commission [5]. During the last episode of STI, $66 \%$ of our sailors had consulted a health professional and $27 \%$ a pharmacist.

The confidential screening test of HIV infection was welcomed by $19 \%$ of our sailors but only $10.2 \%$ had done it. This rate was of $25.5 \%$ in sex professionals, $9.7 \%$ in injectable drug users and $4.5 \%$ in the general Moroccan population aged 15 to 49 years old [2].

\section{CONCLUSIONS}

This study has shown a gap in the level of knowledge about modes of transmission and prevention of AIDS/HIV infection and the risky sexual behaviours. The seafarers form quite a vulnerable population. Unprotected sexual intercourses, multi-sexual partnerships as well as toxic habits were the main behavioural determinants. The stigmatisation and discrimination towards HIV positive people remain 
important. Strengthening information actions, education, communication and awareness is necessary.

\section{REFERENCES}

1. ONUSIDA. Rapport sur l'épidémie mondiale de sida. ; 2014: 1-5.

2. Ministère de la santé du royaume du Maroc.Mise en œuvre de la déclaration politique sur le VIH/sida. Rapport National; 2014: 8-15.

3. Mulić R, Vidan P, Polak NK. HIV infection among seafarers in Croatia. Int Marit Health. 2010; 62(4): 209-214, indexed in Pubmed: 21348014.

4. Nikolić N, Nikolić N. Global partnership on HIV and mobile workers in the maritime sector. Int Marit Health. 2010; 62(4): 189-194, indexed in Pubmed: 21348011.

5. Ng Man Sun R. Projet d'Appui à l'Initiative Régionale de prévention des IST/VIH/sida (AIRIS). Etude socio-comportementale au VIH/ Sida parmi les marins dans les pays membres de la Commission de l'Océan Indien (Comores, Madagascar, Maurice et Seychelles; 2008: 22-49.

6. Efunsile AM, Oduyebo 00, Oyibo WA, et al. Knowledge, attitude and practice of the trainee seafarers to HIV/AIDS and STIs at Apapa Seaport, Lagos. African J Clin Exp Microbiol. 2007; 8(2): 94-100, doi: 10.4314/ajcem.v8i2.7469.
7. Faye A, Faye MD, Leye MM, et al. Knowledge and attitudes of Senegalese sailors about HIV/AIDS. Int Marit Health. 2013; 64(3): 148-153, indexed in Pubmed: 24072542.

8. Faye A, Faye MD, Leye MM, et al. Étude des déterminants des rapports sexuels non protégés chez les marins de la marine marchande sénégalaise. Bulletin de la Société de Pathologie Exotique. 2014; 107(2): 115-120, doi: 10.1007/s13149-014-0353-x.

9. Robate M, Toatu T, Kirition R, et al. Sexual behaviour of Kiribati seafarers: second generation surveillance in 2005 and 2008. Int Marit Health. 2010; 62(4): 195-200, indexed in Pubmed: 21348012.

10. Saniel OP, De los Reyes SJ. Prevalence of risky behaviours and determinants of multiple sex partnerships among male Filipino seafarers. Int Marit Health. 2010; 62(4): 215-223, indexed in Pubmed: 21348015.

11. Grappasonni I, Paci P, Mazzucchi F, et al. Sexual behaviour of Kiribati seafarers: second generation surveillance in 2005 and 2008. Int Marit Health. 2010; 62(4): 195-200, indexed in Pubmed: 21348012.

12. Bailey A. Left at sea: HIV vulnerability among migrant fishermen in Goa, India. Int Marit Health. 2011; 62(2): 116-122, indexed in Pubmed: 21910115.

13. Guevara N, Pineda M, Dorotan M, et al. Cross-sectional survey on the knowledge, attitude and practice of male Filipino seafarers on sexual health. Int Marit Health. 2010; 62(4): 224-232, indexed in Pubmed: 21348016. 